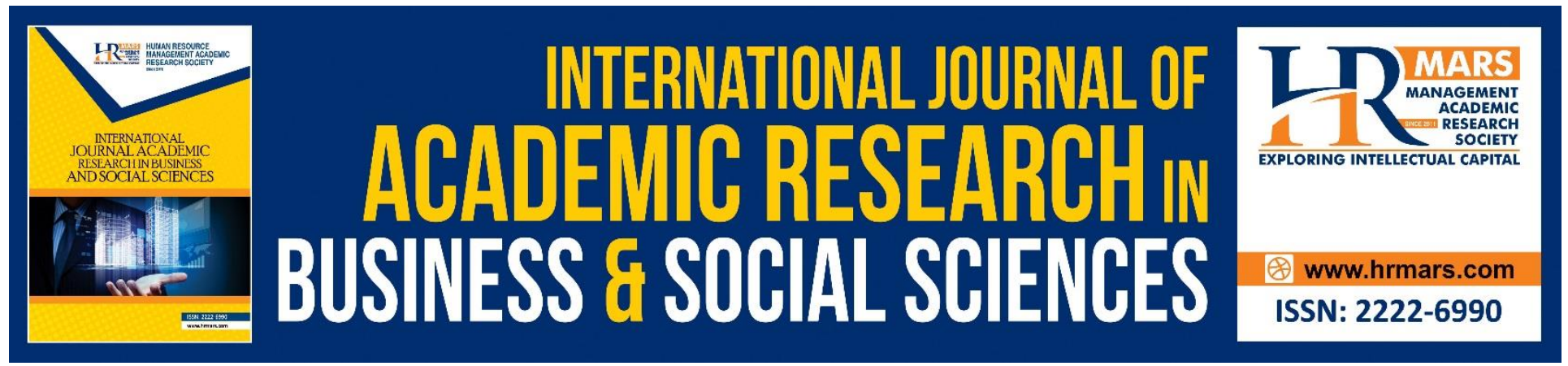

\title{
Law and Moral Values in the Holy Qur'ān
}

\section{Mohamed Fathy Mohamed Abdelgelil, Mukhamad Hadi Musolin, Reda Owis Hassan Serour, Mohd Shaifulbahri Abdullah, Mariam Nabilah Mohd Noor}

To Link this Article: http://dx.doi.org/10.6007/IJARBSS/v8-i11/4915

DOI: $10.6007 /$ IJARBSS/v8-i11/4915

Received: 18 Oct 2018, Revised: 09 Nov 2018, Accepted: 21 Nov 2018

Published Online: 28 Nov 2018

In-Text Citation: (Abdelgelil, Musolin, Serour, Abdullah, \& Noor, 2018)

To Cite this Article: Abdelgelil, M. F. M., Musolin, M. H., Serour, R. O. H., Abdullah, M. S., \& Noor, M. N. M. (2018). Law and Moral Values in the Holy Quran. International Journal of Academic Research in Business and Social Sciences, 8(11), 445-451.

Copyright: (C) 2018 The Author(s)

Published by Human Resource Management Academic Research Society (www.hrmars.com)

This article is published under the Creative Commons Attribution (CC BY 4.0) license. Anyone may reproduce, distribute, translate and create derivative works of this article (for both commercial and non-commercial purposes), subject to full attribution to the original publication and authors. The full terms of this license may be seen at: http://creativecommons.org/licences/by/4.0/legalcode

Vol. 8, No. 11, 2018, Pg. 445 - 451

http://hrmars.com/index.php/pages/detail/IJARBSS

JOURNAL HOMEPAGE

Full Terms \& Conditions of access and use can be found at http://hrmars.com/index.php/pages/detail/publication-ethics 


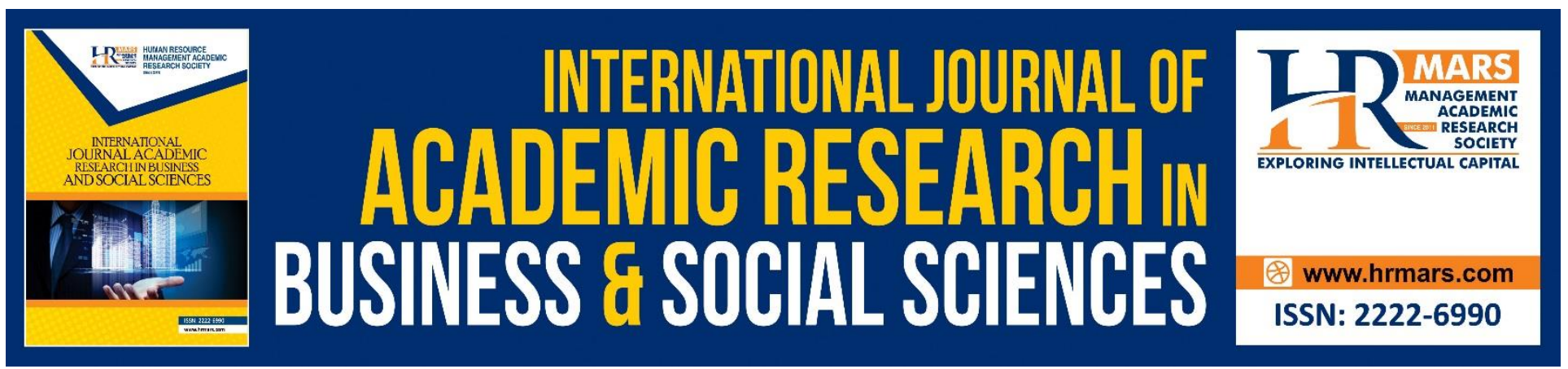

\title{
Law and Moral Values in the Holy Qur'ān
}

\author{
Mohamed Fathy Mohamed Abdelgelil \\ Faculty of Islamic Contemporary Studies, UniSZA \\ Corresponding Author: mfathy@unisza.edu.my \\ Mukhamad Hadi Musolin \\ Reda Owis Hassan Serour
}

Faculty Of Usuluddin \& Quranic Sciences, Sultan Abdul Halim Mu'adzam Shah International Islamic University

\author{
Mohd Shaifulbahri Abdullah \\ Mariam Nabilah Mohd Noor \\ Faculty of Islamic Contemporary Studies, UniSZA
}

\begin{abstract}
The laws were designed only to make humanity safe and secure with justice, dignity and freedom. Law scholars took every precaution to guarantee the right of people to life. However, in order for some not to think that these laws should be kept away from the Holy Qur'ān, this article has been written as a guide for the person to keep moral values and Islamic principles. The Holy Qur'ān is the only constitution of religious and secular morality, whereas its' ethics can be applied at any time and place. If the laws abandoned the verses of the Qur'ān, they became laws without a spirit. This is because they only address the body not the soul, and observes apparent actions and not internal. As a result of these deficiencies, several schemes and tricks have been formed making it easy to violate the law, and increasing the number of crooks and the spreading of thievery. All of this will be in the name of the law, under its umbrella, or anything of the likes. The purpose of this research is to call for the duplication of the established law along with using the Perfect Qur'anic Law and to focus on addressing the soul and the body together. This will raise the society's security and ethics. In this research, (I) used the analytical method and followed the Qur'ānic verses which the ethics of law were revealed and concluded that the law that makes mankind in the ascendancy always towards religion and creation is the Perfect Qur'ānic Law, and that the laws of life must be derived from the Holy Qur'ān. Furthermore, it also concluded the importance of using the Holy Qur'ān for establishment and enactment of laws in order to be valid for all of mankind.
\end{abstract}

Keywords: Values, Characteristics, Ethics, Holy Qur'ān, Law, Constitution. 


\section{Introduction}

The Perfect Qur'ānic Law is suitable for all times and places which anyone can easily move upon its path and under any circumstances. Indeed, it has established laws for the youth and the elder and for men and women. As a matter of fact, even laws for the fetuses in their mothers' wombs were not forgotten. This is pertaining to personalities but as for their destinations and their lifestyles, it has explained for them everything in detail. It has created for them a path of happiness for both this worldly life and the hereafter. It has explained for them their ways of interactions; physically, personally, with family and community. Likewise, it explained to them as well their relationships between one another even if they were from different social levels. The Qur'ānic Law has clarified how the relationships should be between the Muslims and non-Muslims living amongst them or abroad, which they could be enemies or those whom they have peace treaties with. It has set boundaries of conduct for the Muslims themselves between the ruler and the ruled, between the son and his father, between the man and his wife, and other than them from the Qur'ānic Moral Laws, which is indispensable to the established manmade laws for the human beings to function in any society.

\section{Conceptual Selection}

So that order to lean of what is discussed in this article, we must turn our attention to the definitions of the most important vocabularies of this topic and they are the following:

1) The definition of Law linguistically and idiomatically.

As for the linguistic definition, the word "Law" is not Arabic, but is originally derived from a Greek term called, "Kanun," which means a straight stick. In general this word expresses integrity and being upright. Therefore, the law is used as the scale for making life function in a proper manner (Muhammad, 2007).

As for the idiomatical meaning of the word of Law, it is a set of rules that regulate the conduct of individuals in society in a binding way and whoever violates them may be subject to punishment (AlSudairi, D.T).

2) Definition of values linguistically and idiomatically.

As for the linguistic meaning, values is the plural of value. .] ( ق ي م ) The Arabic letter (ي ) Ys originally a (و)Waw. So Qaf, Waw and Meem is an authentic origin that means raising or determined. You say "I raised something straight up." The original letter of Al-Qimah is Waw because originally you stay in the place of him. (IbnFares, 1979)

And from the meanings of value, it means integrity, uprightness, and justice (Ar-Razi, 1999)

The idiomatical meaning of values is unlimited, because its' meaning is according to each art, trends and opinions. However, based on the previous linguistically definitions, we try to reach a meaning that suits the discussion in question: value is a legitimate, moral standard that distinguished through it the good or bad behavior.

3) Definition of ethics linguistically and idiomatically.

As for the linguistic meaning, ethics is the plural ethic. (The Arabic letters ( $\dot{\tau})$ Khaa (J) Laam and (ق)Qaaf stand for the amount of something and it means the character. (Ibn Fares, 1979) Ethics also refers to nature and religion (Ibn Mantoor, 1994) So ethics is usually the opposite. Formation of the 
INTERNATIONAL JOURNAL OF ACADEMIC RESEARCH IN BUSINESS AND SOCIAL SCIENCES

Vol. 8, No. 11, Nov, 2018, E-ISSN: 2222-6990 @ 2018 HRMARS

internal characteristics of a person. Also it is known as pleasant and unpleasant, so you say, "Good and bad characteristics." For example, the characteristic of giving money, the donator must have the intention only for the Pleasure of Allāh, or it not then it is showing off.

As for the idiomatic meaning of ethics, it is the good behavior patterns that originate from the mind and (Islamic) religious background. (Al-Jorjani, 1983) Having good ethics is to carry good behavior, whether this behavior is apparent or mystical, which is issued by man with a will and aims to achieve goal. (Ali, 2003). It is a knowledge that explains the meaning of good and evil, and what must be the people in their dealings and purposes. (Amin, 1931)

4) Al-Qur'ān linguistically, it is derived from the Arabic letters ق ر Qaf and Raa and at the end of the word a vowel letter which was replaced by a consonant letter which refers to a collection or gathering together. (Ibn Fares, 1979)

It was named Qur'ān because it is a collection and placement of chapter and verses (Ar-Razi, 1995, 560). What seems to be apparent from the numerous linguistic definitions of the Qur'ān, is that indeed it is proof of a combination of placement, collection and recitation ( $\bar{A} l$ Ismael, 2000).

As for the idiomatic meaning of the Qur'ān, it is the Speech of Allāh (God) revealed to His Messenger Muhammad (May the blessings and peace of Allāh be upon him), which its' recitation is worshipping Allāh (God), transmitted several times (by gathering the memorized verses and recitations from the Companions) and then written into book form. Upon this meaning, it is deprived of its major specialties and main purposes (Ismail, 1999, 10; Al-Roumi, 1999, 12).

\section{The Need of Law for the Qur'ānic Ethics}

The law and ethics are both faces of the same coin which should not be separated from each other. They were found in the creation of mankind but whenever they are separated from each other, mankind live in total darkness. The law needs to be united with ethics side by side, and we will take proof from the Holy Qur'ān for that. Although the purpose of the law is to stabilize the society with a system that makes it a safe and beneficial, the desired purpose of the Qur'anic ethics is to elevate the individual towards spiritual values. So, the society's need for ethics is as important as its need for law. The upright religion of Islam did not begin with jurisdiction nor did it draw the boundaries immediately after its' message was sent, but it began first by appealing to moral education.

The law imposes that no person is to attack each other, and when someone assaulted another human being, then the law says that the aggressed has the right to defend himself. As for the story of Adam's sons, we find that Abel gave up his right in law in the case of self-defense down to the superiority of the moral side. This is in the statement of Allāh The Most High,

"If you do stretch your hand against me to kill me, I shall never stretch my hand against you to kill: 'For I fear Allāh (God) Lord of everything that exists." [Sūrah Al-Mā'idah 5:28].

If the law requires people to respect other people's money and private properties, then the Qur'anic ethics show the extent of the charity that existed in the hearts. This is the same as when Abu Bakr (May Allāh be pleased with him) spent his money to buy Bilal (May Allāh be pleased with him) and emancipated him to rescue him from the torture he got by his master following the verse:

"By no means shall you attain righteousness until you spend (in the cause of Allāh) of that which you love." [Sūrah Āli Imrān 3:92] 
Abu Bakr (May Allāh be pleased with him) did not think of the law that was with him, he thought about the moral aspect of the Holy Qur'ān. This is what made Omar Bin Al-Khattab (May Allāh be pleased with them) say about this story: "Abu Bakr, our master and freed our master," he meant Bilal. Omar called Bilal a master, because knew the rightly guided Qur'ānic law in the verse:

"Verily, the most honorable of you with Allāh (God) is the most fearful/pious." [Sūrah Al-Hujurāt 49:13]

Yes, this is the ethics of the Qur'an.

So, laws, "Laws that were placed by the people are motivated by the need to use them, even if assuming that they adhere to the principle of justice. Verily, is has stated that the murderer should receive the death penalty, but it doesn't harm the same person who is determined to commit the crime, meaning fear is present but does not make him better. As for the Islamic Legislation, a person who judges himself is at least temporary, and in order to be able to judge himself, he can also fear falling into sin that feels great," (Hilmi2004, 107). As written in Qur'ān:

"Whoever kills a believer intentionally, his recompense is Hell to abide therein; and Wrath and Curse of Allāh is upon him." [Sūrah An-Nisā 4:93]

"The voice that he preaches from within himself has first warned him that he is advised before he blames him, whereas the basis of faith in the afterlife in the Islamic direction of morality is one of the most important foundations for building morals in the process of adhering to it. Without it, morality loses its sanctity and its strong influence on mankind. This is not the basis of moral behavior, but rather the basis of life. There is no meaning to life, in fact, without this foundation and without relying on it," (Hilmi 2004, 107)

The law deals only with the aspects that legitimize society's actions and statements and its apparent behavior with other members of society. With this being the case, the law addresses the moral and social aspects that govern the behavior of the individual towards his counterpart in the society in which people live. In the context of this framework, there may by it be subject to punishment. So every statement or action within this context each person avoids those punishments without taking intention into consideration, and without addressing the spirits and values. However, the beholder of the values and ethics contained in the Holy Qur'ān finds that it shapes behavior and deals with the internal exactly as it does with the apparent. So manmade laws are in dyeing need of Qur'ānic Laws so that the society will be elegant in its behavior and relations.

If the rules of law derive their source from the rules and values of ethics in the Holy Qur'àn, good will spread in society and eradicate evil from the souls of people, and the relationship between them will become moral and spiritual relations, and not apparent legal relations.

\section{The Relationship between Qur'ānic Law and Ethics}

The Qur'ān is the origin of Islamic ethics, linking between words, deeds, laws, values and behaviors in an effective and joyful manner. It combines the most important complete legal rules of a happy life that leads to the desired end of every individual in society. Indeed, it has put everyone right in its' place according to wisdom and justice. From one of the most important rules of ethics in the Qur'an is the persistence of ethical values in a law that does not change and cannot be replaced because it is from Allāh (God) and this is called the legal obligation, and of course leads to the responsibility that in its existence, the individual and society are in the best performance. The legal rules in the Holy 
Qur'an are endless Walt, illuminating the path of the various aspects of religious, social, legal, military and personal life.

Dr. Abdullah Draz said, "While legal punishment and moral punishment, naturally each doesn't directly affect only one element that differs from the person (the sense or the conscience), what distinguishes the divine punishment is that it must be wholly and fully. Naturally, this composite punishment is not flawed, but it seems the opposite of that to us. A condition in its perfection is that it agrees with the structure of human nature, as we know it today, and it seems that this nature will remain until the contrary is proven. Keeping its identity, I mean by this close connection between the physical and moral aspects, and also, we now see the spaciousness of the Qur'anic mentioning of punishment. Indeed, they are not special tendencies for man, because they were universal in their purpose, they also wanted to be comprehensive through their approach." (Draz, DT, 416)

Thus, there is a close connection between the legal rules that guide the life and the values and ethics of the Qur'ān that illuminate them. They both regulate the behavior of the individual and the community, likewise neither of them addresses a single individual. Rather, the discourse applies to all members of the society and both of them contain obligation, responsible and reprehensible.

If we look at the idea of obligation, for example, which there is no law without it, where it is "the basic rule and the center and nuclear element which the whole moral system revolves around, and anything which leads to losing it will crush the essence of practical wisdom itself, and the termination of its essence. If there is no longer an obligation, there will be no responsibility and if there is no responsibility, justice cannot prevail. At that time chaos will spread, there will be disorder and barbarism, not only in the field of reality, but also in the field of law, according to the so-called moral principle "(Draz, D., 21).

If we search in the Holy Qur'ān, we find that it mentioned the different types of obligations. Allāh The Most High said:

"And will you take My Covenant. They said "We agree." He said: "Then bear witness; and I am with you among the witnesses." [Sūrah Āli Imrān 3:81]

It obliged the one who is able and excused the one who is incapable. It also lightened the burden upon the one who is weak according to his weakness, but obliges the one who is able. For example, in the statement of Allāh:

"Oh, you who have believed, save yourself and your family from the Hell-fire." [Sūrah At-Tahrim 66:6] And pardoned the one who is incapable like that mentioned in the statement of Allāh:

"There is no restriction on the blind, nor any restriction on the lame, nor any restriction on the sick." [Sūrah An-Nur 24:61]

And it lightened the burden upon the weak according to his weakness like that mentioned in the statement of Allāh:

"Allāh burdens not a person beyond his scope." Sūrah Al-Baqarah 2:286]

There is a great overlap and a clear link between the law and the Rightly -Guided Qur'ānic ethics. Many legal rules are at the same time considered ethical rules derived from the Holy Qur'ān. The legal rules that prohibit and criminalize assaults on the self and the money whether by theft or deceit or even by searching for money without effort, as well as binding the rules of the law or to those who 
INTERNATIONAL JOURNAL OF ACADEMIC RESEARCH IN BUSINESS AND SOCIAL SCIENCES

Vol. 8, No. 11, Nov, 2018, E-ISSN: 2222-6990 (C) 2018 HRMARS

cause harm to others, for example, then all of these, although they are purely legal rules, except they are considered moral laws derived from the Holy Qur'ān.

\section{Conclusion}

Through the previous lines in which the researcher spoke about the laws and moral values in the Holy Qur'ān, and the need for the law of the Qur'ānic values, and the extent of their connection, the following results emerged:

1. The law's need for Qur'ānic values and ethics to create an integrated society that deals with values and ethics because it is owned by its spirit and does not deal with the law out of fear of punishment alone.

2. Laws of life must be derived from the Holy Qur'ān.

3. The interest of the Holy Qur'ān is evident in the enactment of laws and their appropriations to be valid for mankind of all kinds and races. And All praise is due to Allāh (God) The Lord of all creation.

\section{ACKNOWLEDGEMENT}

This paper is sponsored by Universiti Sultan Zainal Abidin (UniSZA). Thanks for sponsoring and supporting this research.

\section{References}

IbnFaris, A. (1979). Mu'jam Maqayis Allugah. Bayrut: Dar Alfikr.

Alraazi, M. A. B. (1995). Mukhtar Alsahah. Bayrut: Maktabat Lubnan Nashirun.

IbnManzor, M.M. (1994). Lisan Alarab. Bayrut: Dar Sader.

Ali, M. Y. (2003). Eilm Al'akhlaq Al'islamiyah. Dar Ilm Alkuteb: Alriyad.

Amin, A. (1931). Kitab Alakhlaq. Dar Alkutub Almasriah: Cairo.

Alsedyry, T. (D. T). Al'islam W Aldstwr. (D. T).

Mohamed, A.T. (2007). Almadkhal Lidirasat Alqanun. (D. T).

Hilmi, M. (2004). Al'akhlaq Byna Alfalasifat W Aulama' Al'iislam. Dar Alkutub Aleilmiah: Bayrut.

Daraz, M.A.A. (D. Ta). Dustur Al'akhlaq Fi Alquran. Muasasat Alresalati: Bayrut.

Al-lismaeil, N.M. (2000). Eilm Alqara'at, Nasha'atuh, 'Atwaruh, 'Atharah Fi Aleulum Alshareiati. Alriyad: Maktabat Altawbat.

Alruwmi, F. (1999). Dirasat Fi Eulum Alquran Alkarim. Alryad: Maktabat Dar Almutaealm. Aljurjani, A. (1983). Altaerifat. Bayrut: Dar Alkitab Alearabi. 